\title{
Correction to: Novel and emerging therapies for B cell lymphoma
}

Sabarish Ayyappan ${ }^{*}$ and Kimi Maddocks

\section{Correction to: Journal of Hematology \& Oncology (2019) 12:82 https://doi.org/10.1186/s13045-019-0752-3}

There is an error in Table 1 of the original article. Lisocabtagene maraleucel (liso-cel) is administered as a flat dose of $1 \times 10^{8}$ CAR $\mathrm{T}$ cells, regardless of a patient's weight. The table incorrectly lists the dose as $1 \times 10^{8}$ cells $/ \mathrm{kg}$.

Published online: 16 February 2021

\author{
Reference \\ 1. Ayyappan S, Maddocks K. Novel and emerging therapies for B cell lym- \\ phoma. J Hematol Oncol. 2019;12(1):82. https://doi.org/10.1186/s1304 \\ 5-019-0752-3.
}

\section{Publisher's Note}

Springer Nature remains neutral with regard to jurisdictional claims in published maps and institutional affiliations.

${ }^{*}$ Correspondence: Sabarish.ayyappan@osumc.edu

Division of Hematology, Department of Internal Medicine, Arthur G.

James Comprehensive Cancer Center, The Ohio State University Wexner Medical Center, 320 W 10th Street, A342 Starling Loving Hall, Columbus,

Ohio 43210, USA original author(s) and the source, provide a link to the Creative Commons licence, and indicate if changes were made. The images or other third party material in this article are included in the article's Creative Commons licence, unless indicated otherwise in a credit line to the material. If material is not included in the article's Creative Commons licence and your intended use is not permitted by statutory regulation or exceeds the permitted use, you will need to obtain permission directly from the copyright holder. To view a copy of this licence, visit http://creativecommons.org/licenses/by/4.0/. The Creative Commons Public Domain Dedication waiver (http://creativeco mmons.org/publicdomain/zero/1.0/) applies to the data made available in this article, unless otherwise stated in a credit line to the data. 